\title{
A SENSITIVITY ANALYSIS ON THE INFLUENCE OF THE EXTERNAL CONSTRAINTS ON THE DYNAMIC BEHAVIOUR OF A LOW POLLUTANT EMISSIONS AIRCRAFT COMBUSTOR-RIG
}

The need to reduce pollutant emissions leads the engineers to design new aeronautic combustors characterized by lean burn at relatively low temperatures. This requirement can easily cause flame instability phenomena and consequent pressure pulsations which may seriously damage combustor's structure and/or compromise its fatigue life.

Hence the need to study the combustor's structural dynamics and the interaction between elastic, thermal and acoustic phenomena. Finite element method represent a largely used and fairly reliable tool to address these studies; on the other hand, the idealization process may bring to results quite far from the reality whereas too simplifying assumptions are made.

Constraints modelling represent a key-issue for all dynamic FE analyses; a wrong simulation of the constraints may indeed compromise entire analyses although running on very accurate and mesh-refined structural models.

In this paper, a probabilistic approach to characterize the influence of external constraints on the modal behaviour of an aircraft combustor-rig is presented. The finite element model validation was performed at first by comparing numerical and experimental results for the free-free condition (no constraints). Once the model was validated, the effect of constraints elasticity on natural frequencies was investigated by means of a probabilistic design simulation (PDS); referring to a specific tool developed in the ANSYS ${ }^{\circledR}$ software, a preliminary statistical analysis was at performed via Monte-Carlo Simulation (MCS) method. The results were then correlated with the experimental ones via Response Surface Method (RSM).

\footnotetext{
${ }^{1}$ Department of Industrial Engineering - Aerospace section University of Naples "Federico II”, Italy; Emails: f.amoroso@unina.it, angelo.defenza@unina.it, giuseppe.petrone@unina.it, rosario.pecora@unina.it
} 


\section{Nomenclature}

$\hat{f}_{\text {natural }}-$ algebraic approximation of natural frequency

CONM2 - lumped mass element type 2 (see NASTRAN reference guide)

DOF - degree of freedom

EMA - experimental modal analysis

FE $\backslash$ FEM - Finite elements $\backslash$ Finite Element method

FREQ - frequency

FRF - frequency response function

HEXA - isoparametric solid element (see NASTRAN reference guide)

$K_{a} \quad-$ stiffness of the zone hit by the hammer along the impact direction

$K_{i} \quad-$ stiffness along i-th degree of freedom

$\dot{m}_{a} \quad-$ air flow rate

MAC - modal assurance criterion

MC - Monte Carlo simulation

$\dot{m}_{f} \quad-$ fuel flow rate

$M_{h} \quad-$ hammer mass

$N_{a} \quad$ - number of modes evaluated by means of numerical analysis (FEM)

$N_{e} \quad-$ number of modes identified by means of experimental tests

$P_{i} \quad-i$-th input variable of the probabilistic method

$P_{\text {in }} \quad$ - internal (combustor) pressure

RBE2 - rigid body element type 2 (see NASTRAN reference guide)

RSM - response surface method

$T_{\text {in }} \quad$ - internal (combustor) temperature

$\left(\Phi_{P}\right)_{j} \quad-j$-th component of vector $\Phi_{P}$

$\left(\Phi_{X}\right)_{j} \quad-j$-th component of vector $\Phi_{X}$

$\Phi_{P} \quad$ - vector of modal displacements coming from source $P$ (source being theoretical analysis or experimental measurement)

$\Phi_{X} \quad-$ vector of modal displacements coming from source $X$ (source being theoretical analysis or experimental measurement)

\section{Introduction}

There is growing urgency to reduce the impact of aviation emissions and there are several options to reach this goal, including changes in aircraft and engine technology, fuel, operational practices, regulatory and economic measures. These could be implemented either singly or in combination.

Technology advances have substantially reduced most emissions per passenger-km. However, there is a potential for further improvements. Any technological change may involve a balance among a range of environmental impacts. 
Subsonic aircraft being produced today are about $70 \%$ more fuel efficient per passenger-km than 40 years ago. The majority of this gain has been achieved through engine improvements and the remainder from airframe design improvement. A $20 \%$ improvement in fuel efficiency is expected by the end of 2015 and a 40 to $50 \%$ by the end of 2050 may be forecast by extrapolating the data of aircraft currently in commerce [1,2]. Engine efficiency improvements reduce the specific fuel consumption and most types of emissions; however, contrails may increase and, without advances in combustor technology, $\mathrm{NO}_{x}$ emissions may also increase. Future engine and airframe design involves a complex decision-making process $[3,4]$ and a balance of considerations among many factors (e.g., carbon dioxide emissions, $\mathrm{NO}_{x}$ emissions at ground level, $\mathrm{NO}_{x}$ emissions at altitude, water vapour emissions, contrail/cirrus production, and noise). Research programs addressing $\mathrm{NO}_{x}$ emissions from supersonic aircrafts are also in progress [5].

All promising approaches aimed at $\mathrm{NO}_{x}$ reduction are based on lean premixing combustion technology that operates with an excess of air to significantly lower flame temperatures and consequently reduce $\mathrm{NO}_{x}$ generation. However, the homogenisation of fuel-air mixture has a strongly adverse effect on combustion lean stability, leading to vibratory combustor failure [6]. This phenomenon may have impacts on combustor integrity when the sustained instability levels excite the acoustical modes of the surrounding structure, thus leading to significant pressure oscillations; these oscillations (with frequencies ranging from hundreds to thousands Hertz) can force the resonance of some structural modes up to the crisis of the entire system [7-11]; hence the need to study the structural dynamic of the combustor and the interaction between elastic, thermal and acoustic phenomena [12-14]. An accurate characterization of combustor dynamics, through its modal parameters, is mandatory for such purpose.

Since tests campaigns are usually expensive and time consuming, numerical simulations using FEM approach are crucial when a fairly representative estimation of investigated structures' dynamics is required. Anyway, the use of the numerical approach alone is prone to mistakes in geometry definition or in material association and these potential mistakes may lead to unreliable numerical results.

In recent years, a significant amount of work has dealt with the evaluation and reduction of the "discrepancies" between numerical and experimental outcomes in the field of structures dynamics. The tuning of the numerical model to match tests results surely represents a largely used method to reduce such discrepancies; on the other hand, it does not represent the unique and most effective approach. 
In this paper, an alternative approach (local method) has been used by referring to the estimation of the uncertain physical parameters while preserving the principal FE properties of the initial model. The identified modification of the model is clearly associated to the physical parameter changes. Many factors influence the vibration properties of combustors, such as geometric tolerances, constraint stiffness, material properties, temperature effects, etc. This study has been focused on the influence of the constraints on the natural frequencies of combustor-rig.

Relying upon a commercial tool available in ANSYS environment [15], a probabilistic approach has been used to evaluate the sensitivity of the numerical modal frequencies to the constraints elasticity. Test results have been used as a baseline to optimize the constraints configuration able to minimize the numerical-experimental frequency gap.

Historically, modal parameters have been preferred as input for model updating since natural frequencies are obtained with great confidence, and modal shapes are a highly condensed database on deformations showed by the structure. During the last years, an increasing group of researchers used frequency domain data - such as FRF - directly resulting from experimental analysis. The first implementation of frequency domain least squares updating was proposed by Lin and Ewins [16]. To overcome the coordinate incompleteness in the measured responses, analytical counterparts at slave (unmeasured) degrees of freedom (DOF) were adopted as a very simple form of FRF expansion. Other researchers moved along a different direction and supported the reduction of the FE model to the measured DOF in different ways (see D'Ambrogio et al. [17], Lammens et al. [18], Pascual et al. [19], for example).

This paper describes how design factors uncertainties can be managed in assessing the basic structural dynamic characteristics of an aero-engine combustor by means of the probabilistic Finite Element Method approach (FEM) implemented in ANSYS environment.

In particular, two different probabilistic design approaches, the Monte Carlo Simulation (MC) [20] and the Response Surface Method (RSM) [21] have been used to characterize the dynamic properties of the combustor-rig. The statistical approaches applied in this paper are extensively treated in literature [22], and so they have been applied without any explicit introduction or analytical formulation. The aero-engine combustor-rig described in this paper has been developed at AVIO Aerospace Propulsion laboratory in Pomigliano d'Arco (Naples, Italy).

Section 2 provides information about the test article, while section 3 is dedicated to the experimental and numerical investigations. Section 4 deals with the analysis of the results, while in section 5 a sensitivity analysis is presented. Finally, some concluding remarks are given in section 6. 


\section{Test specimen}

The reference structure investigated in this work is the combustor CLEAN (Component vaLidator for Environmentally - friendly Aero eNgine) developed by AVIO S.p.A.

The combustor (Fig. 1) is characterized by low pollutant emissions and is equipped with two types of injectors: 18 traditional PILOT and 18 MAIN LPP (Learn Premixed Pre-vaporised). The internal design ensures a good mixture ratio to get a massive $\mathrm{NO}_{x}$ reduction. Main chamber data are listed in Table 1, where $P_{i n}$ and $T_{i n}$ are the internal pressure and temperature while $\dot{m}_{a}$ and $\dot{m}_{f}$ are, respectively, air and fuel flow rates.
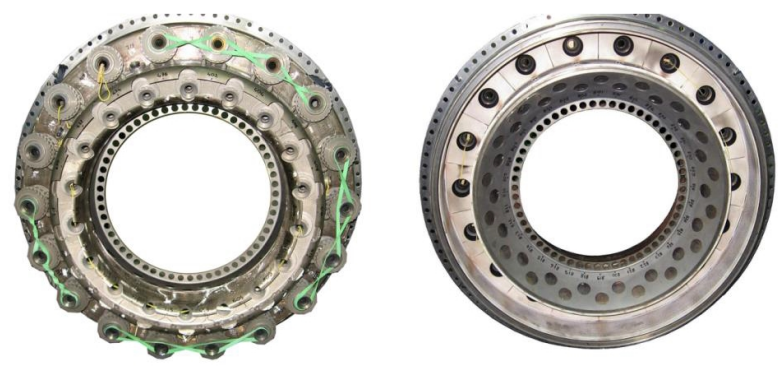

Fig. 1. Combustor CLEAN

Characteristics of the combustor CLEAN

Table 1.

\begin{tabular}{|c|c|}
\hline$P_{\text {in }}$ & $33 \mathrm{bar}$ \\
\hline$T_{i n}$ & $900 \mathrm{~K}$ \\
\hline$\dot{m}_{a}$ & $35 \mathrm{Kg} / \mathrm{s}$ \\
\hline$\dot{m}_{f}$ & $1.20 \mathrm{Kg} / \mathrm{s}$ \\
\hline
\end{tabular}

The combustor chamber is made of Hastelloy- $X$, an high performance alloy, very common in gas turbines and particularly suitable for high temperature loads.

Material properties are strongly dependent on temperature and this dependence was duly taken into account. Young's modulus exhibits a 35\% reduction (from $\sim 200 \mathrm{GPa}$ up to $\sim 130 \mathrm{GPa}$ ) while temperature increases from $20^{\circ} \mathrm{C}$ up to $900^{\circ} \mathrm{C}$ (Fig. 2). Poisson ratio value was assumed constant and equal to 0.312 . This was believed reasonable since several measurements proved that this parameter is slightly affected by temperature changes. Finally, material density was considered equal to $8220 \mathrm{Kg} / \mathrm{m}^{3}$ irrespectively of combustor working temperature. 


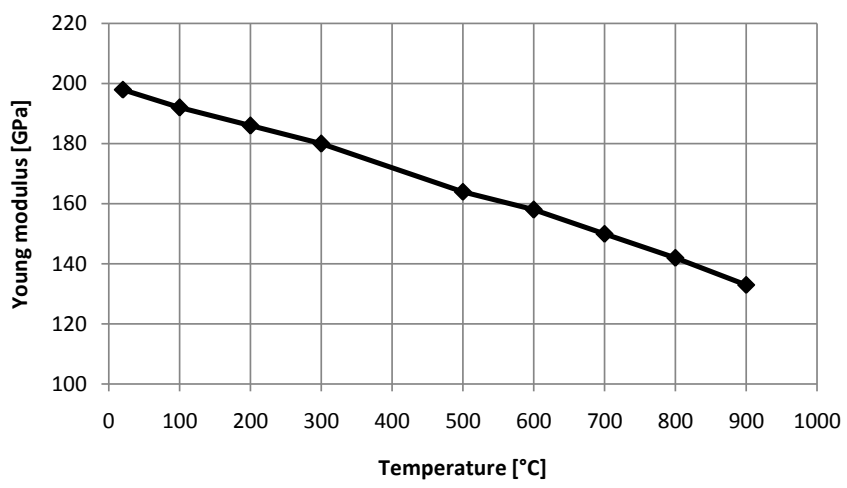

Fig. 2. Young's modulus vs. temperature

\section{Investigations}

Numerical analyses were carried out to evaluate natural modes and frequencies of the test-article while considering different constraints conditions. Experimental tests were then addressed to identify modal parameters and results were correlated to numerical expectations in order to properly tune and validate the FE model of the combustor.

\subsection{Experimental investigation}

Modal parameters of the combustor were identified through resonance tests adopting the so-called roving hammer technique [18-23]. In Fig. 3 the experimental setup has been shown. The external flanges of the combustor were fixed to a rigid support through soft springs; the stiffness of the spring was defined in order to reproduce - with good approximation - a typical free-body constraint condition.

An instrumented hammer was used to hit the structure with an impulsive load; the mass of the hammer was conveniently chosen in order to reach the desired value of maximum excitation frequency; if $K_{a}$ is the stiffness of the impact area and $M_{h}$ the hammer mass, the highest excitation frequency results, in fact, proportional to the root square of the ratio $K_{a} / M_{h}$. Two series of excitation points and directions were defined in order to identify modal shapes with more accuracy (Fig. 4a):

1. $2 \mathrm{XX}$ points series with excitation along radial direction (typical for cylindrical modes identification);

2. $3 \mathrm{XX}$ points series with excitation along axial direction (typical for axial-symmetric modes identification).

Three-axial accelerometers (model PCB 352B10) were used to measure the accelerations on the acquisition nodes. A set of 150 acquisition points 

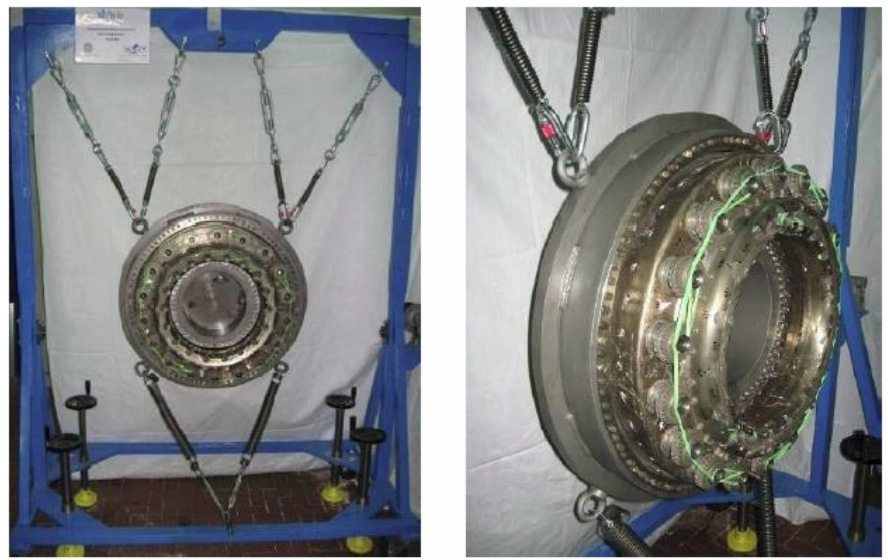

Fig. 3. Experimental set-up: details on boundary conditions

equally spaced in a circumferential way distributed in 8 flanges of the combustor chamber (Fig. 4b) was properly located on test article in order to avoid aliasing phenomena. Preliminary FE analyses have shown that the number of acquisition points chosen, less than the numerical one, are able to ensure a correct extraction of modal shapes [24]. Moreover, since the instrumented hummer is not able to ensure a perfect repetitiveness like e.g. the pneumatic gun used by De Fenza et al. [25], each node of the experimental mesh was excited five times. The resulting FRF were then averaged in order to get a unique response function for each node.

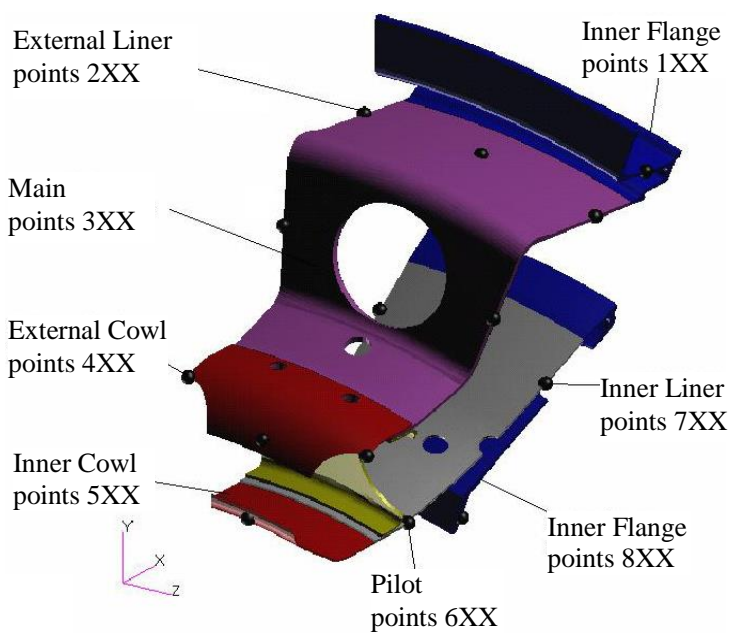

(a)

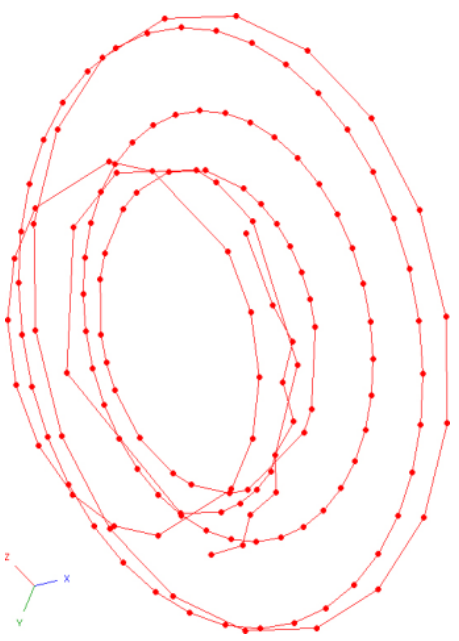

(b)

Fig. 4. Excitation points (a) and experimental mesh grid (b) 
Frequency response data were recorded and then analysed by adopting PolyMAX function implemented in LMS Test.Lab 8B commercial software.

\subsection{Numerical analysis}

Finite element analysis of the combustor was carried out in ANSYS environment [17]. The FE model was generated in MSC Patran; in order to achieve a refined simulation of stress distribution, the structural mesh was prevalently based on 8-nodes HEXA elements (HEXA 8). The injectors were modelled as a lumped mass (CONM2) located at injectors' centre of gravity and connected by means of rigid body elements (RBE2) to the surrounding structure. The full FE model (Fig. 5) consisted of 481463 nodes, 323064 HEXA elements, 36 lumped mass and 180 Multi-Point Constraints. The combustor chamber was assumed clamped at support flanges and modal parameters were evaluated in the frequency range $0-1000 \mathrm{~Hz}$ referring to Lanczos method.

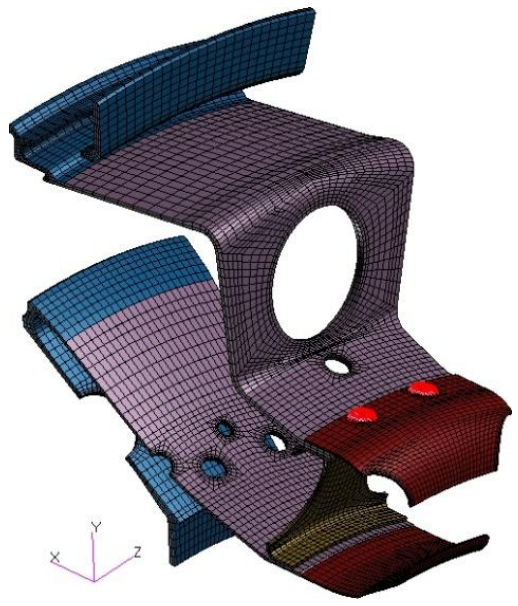

(a)

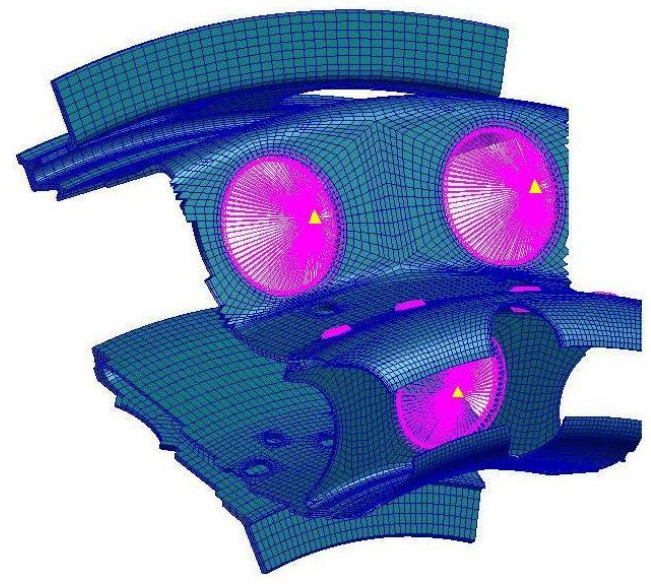

(b)

Fig. 5. Isometric view of the full (a) and detail (b) combustor FE model section

\subsection{Numerical-experimental correlation approach}

Correlation between experimental and numerical modes was performed by evaluating the Modal Assurance Criterion index (MAC). The MAC index is a scalar parameter measuring the degree of consistency (linearity) between modal vectors originated from two different sources (experimental tests and FE analyses in our case). The MAC index of two modal vectors $\Phi_{X}$ and $\Phi_{P}$ originating respectively from sources $X$ and $P$ is defined as follows: 


$$
\operatorname{MAC}(p, x)=\frac{\left|\sum_{j=1}^{n}\left(\Phi_{X}\right)_{j}^{T}\left(\Phi_{P}\right)_{j}\right|^{2}}{\sum_{j=1}^{n}\left(\Phi_{X}\right)_{j}^{T}\left(\Phi_{X}\right)_{j} \sum_{j=1}^{n}\left(\Phi_{P}\right)_{j}^{T}\left(\Phi_{P}\right)_{j}}
$$

where $n$ stands for the size of each vector.

If the MAC index has a value near to zero, then the modal vectors are not consistent. On the other hand, if the MAC index has a value near the unity, the modal vectors coming from the different sources are consistent. MAC index was computed between the $N_{e}$ modal vectors identified through experimental data and the $N_{a}$ modal vectors evaluated from finite element analysis. This process resulted in a $N_{e} \times N_{a}$ rectangular MAC matrix with values that approached unity, whereas an experimental modal vector and an analytical modal vector resulted consistently related.

\section{Results}

The dynamic behaviour of the aircraft combustor-rig, in terms of natural frequencies and mode shapes, was investigated numerically and experimentally. First results were obtained for the test article under free-free boundary conditions in order to validate the numerical model. In Table 2, the experimental frequencies in the range $0-500 \mathrm{~Hz}$ are correlated with the numerical ones.

With the only exception of the last couple of modes, MAC index resulted higher than $65 \%$ thus showing good correlation level in terms of modes shape. On the other side, a pretty high difference between numerical and experimental frequencies was found (average percentage difference equal to nearly $20 \%$ ).

Table 2.

Correlation results: FEA vs. EMA

\begin{tabular}{|c|c|c|c|c|c|}
\hline \multicolumn{2}{|c|}{$\begin{array}{c}\text { Numerical results } \\
\text { (FEA) }\end{array}$} & \multicolumn{2}{c|}{$\begin{array}{c}\text { Experimental results } \\
\text { (EMA) }\end{array}$} & Difference & MAC \\
\hline $\begin{array}{c}\text { Mode shapes } \\
\#\end{array}$ & $\begin{array}{c}\text { Frequency } \\
{[\mathrm{Hz}]}\end{array}$ & $\begin{array}{c}\text { Mode shapes } \\
\#\end{array}$ & $\begin{array}{c}\text { Frequency } \\
{[\mathrm{Hz}]}\end{array}$ & {$[\%]$} & {$[\%]$} \\
\hline 1 & 102.9 & 1 & 81 & 26.52 & 90.3 \\
\hline 2 & 207.4 & 2 & 169 & 22.9 & 73.2 \\
\hline 3 & 252.4 & 3 & 199 & 26.98 & 85.9 \\
\hline 4 & 269.6 & 4 & 251 & 7.53 & 64.7 \\
\hline 5 & 292.0 & 5 & 231 & 26.6 & 93.6 \\
\hline 6 & 474.3 & 6 & 474 & 0.13 & 68.1 \\
\hline 7 & 496.7 & 7 & 289 & 71.7 & 50.3 \\
\hline
\end{tabular}


In order to improve this correlation, an update of the FE model was performed. The update concerned the modelling of small holes (having diameter lower than $1 \mathrm{~mm}$ ) initially neglected in some regions of the structure. In order to save computational time, the effects of the holes were simulated by lowering the Young's modulus of the material all along the interested regions. The results obtained with the updated numerical model are reported in Table 3; evident improvements were obtained in terms of MAC index and frequencies correlation.

Table 3.

Correlation results: FEA vs. EMA after update

\begin{tabular}{|c|c|c|c|c|c|}
\hline \multicolumn{2}{|c|}{$\begin{array}{c}\text { Numerical results } \\
\text { (FEA) }\end{array}$} & \multicolumn{2}{c|}{$\begin{array}{c}\text { Experimental results } \\
\text { (EMA) }\end{array}$} & Difference & MAC \\
\hline $\begin{array}{c}\text { Mode shapes } \\
\#\end{array}$ & $\begin{array}{c}\text { Frequency } \\
{[\mathrm{Hz}]}\end{array}$ & $\begin{array}{c}\text { Mode shapes } \\
\#\end{array}$ & $\begin{array}{c}\text { Frequency } \\
{[\mathrm{Hz}]}\end{array}$ & {$[\%]$} & {$[\%]$} \\
\hline 1 & 83.8 & 1 & 81 & 3.06 & 85.7 \\
\hline 2 & 188.2 & 2 & 169 & 11.53 & 79.2 \\
\hline 3 & 209.9 & 3 & 199 & 5.48 & 55.5 \\
\hline 4 & 224.5 & 4 & 231 & -2.65 & 93.7 \\
\hline 5 & 239.0 & 5 & 251 & -4.7 & 88 \\
\hline 6 & 316.5 & 6 & 289 & 9.41 & 81.2 \\
\hline 7 & 438.0 & 7 & 474 & -7.55 & 73.3 \\
\hline
\end{tabular}

Once the numerical model was updated and validated, a study of the influence of the constraints on the dynamic behaviour of the combustor was performed.

Table 4 reports the natural frequencies of the combustor rig with clamped flanges. Experimental frequencies result always lower than numerical ones

Table 4.

Correlation results: FEA vs. EMA

\begin{tabular}{|c|c|c|c|c|c|}
\hline \multicolumn{2}{|c|}{$\begin{array}{c}\text { Numerical results } \\
\text { (FEA) }\end{array}$} & \multicolumn{2}{c|}{$\begin{array}{c}\text { Experimental results } \\
\text { (EMA) }\end{array}$} & Difference & MAC \\
\hline Mode shapes & $\begin{array}{c}\text { Frequency } \\
{[\mathrm{Hz}]}\end{array}$ & Mode shapes & $\begin{array}{c}\text { Frequency } \\
{[\mathrm{Hz}]}\end{array}$ & {$[\%]$} & {$[\%]$} \\
\hline 1 & 415.42 & 2 & 360.50 & 13.22 & 17.2 \\
\hline 2 & 441.24 & 1 & 347.24 & 21.30 & 38.9 \\
\hline 3 & 464.51 & 4 & 469.13 & -0.99 & 25.8 \\
\hline 4 & 595.25 & 3 & 423.83 & 28.79 & 79.0 \\
\hline 5 & 683.78 & 5 & 575.51 & 15.83 & 53.6 \\
\hline 6 & 765.30 & 6 & 704.41 & 7.95 & 61.3 \\
\hline 7 & 856.24 & 7 & 631.85 & 26.20 & 23.7 \\
\hline
\end{tabular}


and this was supposed to be due to the rigid constraint hypothesis implicitly assumed in numerical model.

\section{Sensitivity Analysis}

Parametric design studies can help in the mechanical design of turbine blades.

In order to appraise the effect of constraints elasticity on modal frequencies, a probabilistic design analysis was carried out. Single point constraints on outer and inner flanges were replaced with a set of three springs mutually orthogonal in a cylindrical reference system, each one characterized by a stiffness value given by

$$
K_{i}=10^{P_{i}}, \quad i=1,2, \ldots 6
$$

where the indices $P_{i}$ are used as input variables for the probabilistic design method. The first three indices (i.e. $i=1,2,3)$ refers respectively to radial $(\mathrm{r})$, tangential ( $t$ ) and axial (a) stiffness constraints of the external flange while the next three indices (i.e. $i=4,5,6$ ) refers respectively to radial, tangential and axial stiffness constraints of the internal one [14, 15] (Fig. 6). All these indices provided several combinations involving several FE simulations.

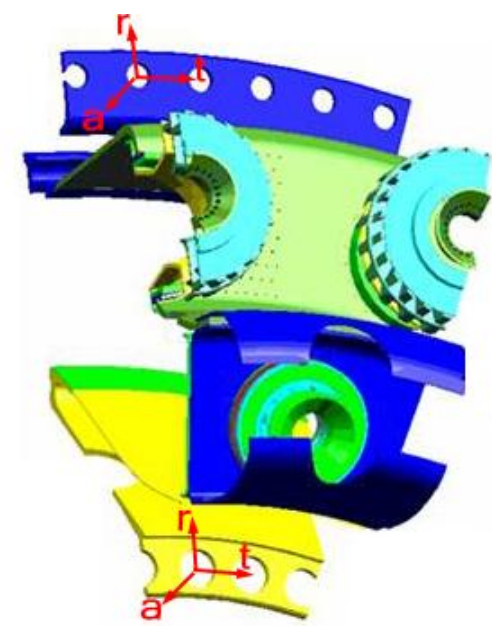

Fig. 6. Cylindrical reference systems on external (up) and internal flange (low)

Fig. 7 shows a comparison between the mode shapes of three selected frequencies. Two probabilistic methods were adopted: Monte-Carlo Simulation (MCS) and Response Surface Method (RSM). In a Monte Carlo simulation [15], input parameters are assigned in a pseudo-random way by direct sampling or Latin hypercube sampling (LHS). 


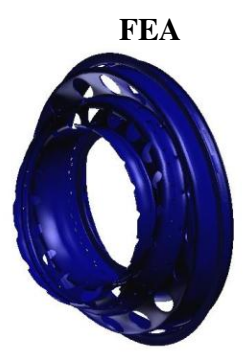

FEA $2(441.24 \mathrm{~Hz})$

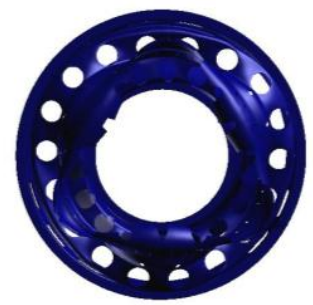

FEA $4(595.25 \mathrm{~Hz})$

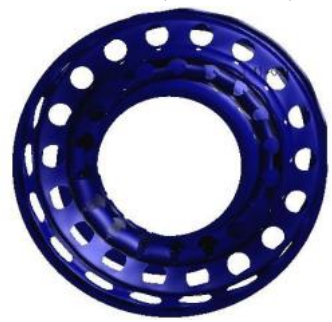

FEA $6(765.30 \mathrm{~Hz})$

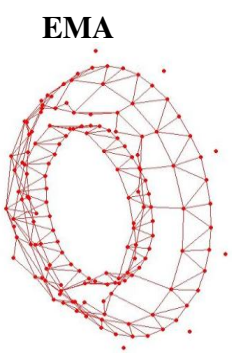

EMA $1(347.24 \mathrm{~Hz})$

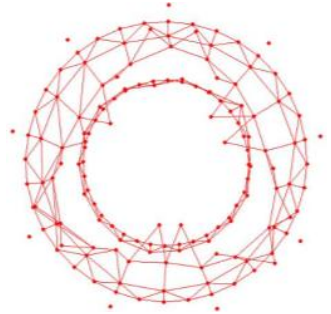

EMA $3(423.83 \mathrm{~Hz})$

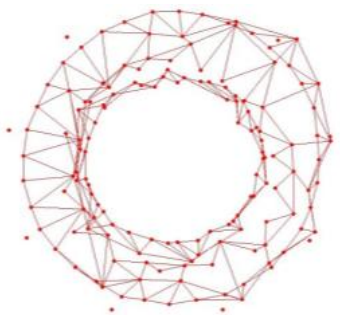

EMA $7(704.41 \mathrm{~Hz})$

Fig. 7. FEA and EMA mode shapes

Direct MonteCarlo Sampling (DMCS) is the most common and traditional form of a MonteCarlo analysis, it is popular because it mimics natural processes that everybody can observe and is therefore easy.

On the other side, it is not the most efficient technique because it requires several simulation loops being the sampling process "without memory".

The latin Hypercube Sampling is much more advanced and efficient; the only difference between LHS and DMCS is that LHS has a sample "memory" thus avoiding the repetition of samples that have been already analysed.

Although Monte-Carlo method provides satisfactorily good results, it requires a lot of computational time. A faster alternative tool is represented by the Response Surface Method (RSM) [16]; such method is based on the assumption that the influence of input variables on output parameters can be approximated by an algebraic function.

RSM locates the sample points in the space of random input variables $\left(P_{i, j}\right)$ so that an appropriate approximation function can be found more efficiently; 
this function is typically a quadratic polynomial. In our case, the approximation function was defined by the following expression:

$$
F=c_{0}+\sum_{i}^{n} c_{i} P_{i}+\sum_{i}^{n} \sum_{j}^{n} c_{i j} P_{i} P_{j}
$$

where: $c_{0}$ is the coefficient of costant term, $c_{i}$ are the coefficient of the linear terms, $c_{i j}$ are the coefficient of quadratic terms.

In order to evaluate the coefficients of eq. (3), a regression analysis is used and the coefficients are usually evaluated such that the sum of squared differences between the true simulation results and the values of the approximation function are minimized,

An RSM analysis consists of two steps:

- Performing the simulation loops to calculate the values of the random output parameters that correspond to the sample points in the space of random input variables.

- Performing a regression analysis to derive the terms and coefficients of the approximation function.

The fundamental idea of RSM is that once the coefficients of suitable approximation function are found, they can be used instead of looping through the FE model.

Response Surface Method requires a less number of simulations than MCS and provides results with reasonable accuracy.

\subsection{Monte-Carlo aimulation}

Monte-Carlo simulation was initially used to investigate the sensitivity of the 2nd, 4th and 6th (numerical) mode shapes to constraints' stiffness; the choice fell on these mode shapes because:

- 2nd and 6th mode shapes have one nodal diameter; the set of equations to be solved depends on number of nodal diameter; the ANSYS solver thus may produce only one set of equations to extract both, which results in a reduction of a few minutes in the run time;

- 4th mode shape has the highest MAC value.

150 Latin Hypercube samplings were considered for input variables. Constraints were assumed to be characterized by same elastic properties along angular direction; a spatially uniform distribution [14] of values was then imposed to input variables $\left(P_{i}, i=1, \ldots 6\right)$ ranging from a minimum of 2 and a maximum of 5. The results of the simulation are reported in Table 5.

They show that the 2nd and 6th frequency (FREQ2, FREQ6) are very sensitive to the changes in constraint stiffness, while the 4th frequency (FREQ4) 
Simulation results

\begin{tabular}{|c|c|c|c|c|}
\hline Parameter & $\begin{array}{c}\text { Mean value } \\
{[\mathbf{H z}]}\end{array}$ & $\begin{array}{c}\text { Standard } \\
\text { deviation }\end{array}$ & $\begin{array}{c}\text { Min } \\
{[\mathbf{H z}]}\end{array}$ & $\begin{array}{c}\text { Max } \\
{[\mathbf{H z}]}\end{array}$ \\
\hline FREQ 2 & 407.3 & 24.85 & 340.3 & 436.0 \\
\hline FREQ 4 & 591.1 & 2.88 & 581.4 & 594.3 \\
\hline FREQ 6 & 637.1 & 46.87 & 535.5 & 725.9 \\
\hline
\end{tabular}

results practically unaffected; this means that the level of correlation of the 4th frequency to its experimental value may be hardly increased by working on constraints only. Hinton graph reported in Fig. 8 shows the correlations between the input variables $\left(P_{i}\right)$ and the investigated natural frequencies (FREQ2, FREQ4, FREQ6). Each square's area represents a weight's magnitude. The data values representative of each square area are reported in Table 6.

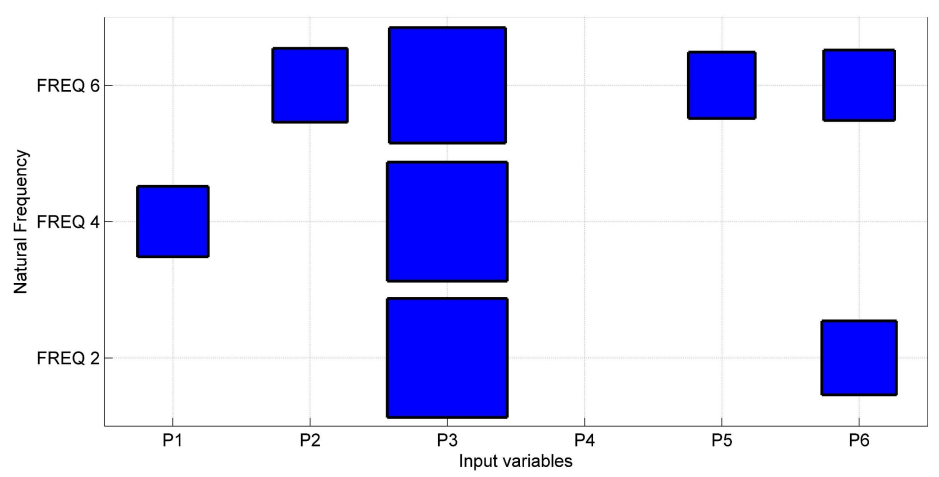

Fig. 8. Hinton graph: natural frequencies vs. input variables

Table 6.

Hinton data: natural frequencies vs. input variables

\begin{tabular}{|l|c|c|c|c|c|c|}
\hline & P1 & P2 & P3 & P4 & P5 & P6 \\
\hline FREQ 6 & 0 & 0.31 & 0.74 & 0 & 0.25 & 0.28 \\
\hline FREQ 4 & 0.28 & 0 & 0.92 & 0 & 0 & 0 \\
\hline FREQ 2 & 0 & 0 & 0.9 & 0 & 0 & 0.31 \\
\hline
\end{tabular}

The results reported in Fig. 8 highlight that the natural frequencies of the combustor chamber are mostly affected by the third axial stiffness of the external flange (P3) while the first axial stiffness of the internal flange (P4) has no effect on the dynamic behaviour. In the following scatter plot, the correlation between FREQ 2 and FREQ 6 is reported.

Fig. 9 shows that there is no combination of input parameters able to satisfy the correlation of both frequencies FREQ2 and FREQ6 with their respectively experimental values, namely, $347 \mathrm{~Hz}$ and $692 \mathrm{~Hz}$ (Table 3). In 
order to furnish the best level of correlation for both FREQ2 and FREQ6, a compromise solution has been set. By adopting the combination of input parameters reported in Table 7, the natural frequencies (FREQ2 and FREQ6) become respectively equal to $394 \mathrm{~Hz}$ and $624 \mathrm{~Hz}$.

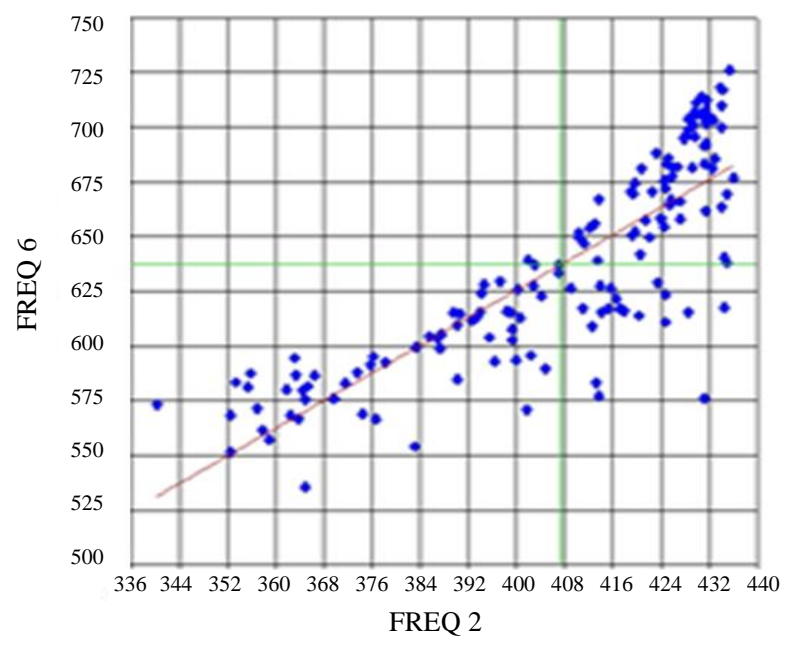

Fig. 9. Scatter plot: FREQ2 vs. FREQ6

Table 7.

Monte-Carlo Method optimal solution

\begin{tabular}{|c|c|c|c|c|c|c|c|c|}
\hline P1 & P2 & P3 & P4 & P5 & P6 & $\begin{array}{c}\text { FREQ 2 } \\
{[\mathrm{Hz}]}\end{array}$ & $\begin{array}{c}\text { FREQ 4 } \\
{[\mathrm{Hz}]}\end{array}$ & $\begin{array}{c}\text { FREQ 6 } \\
{[\mathrm{Hz}]}\end{array}$ \\
\hline 3.03 & 4.02 & 2.57 & 2.80 & 3.32 & 2.86 & 394 & 591 & 624 \\
\hline
\end{tabular}

\subsection{Response Surface Method}

Once the combination of parameters was found, the analysis based on Response Surface Method took place. According to (3), the influence of input variables $\left(P_{i}\right)$ on natural frequencies was approximated by the following algebraic function:

$$
\hat{f}_{\text {natural }}=c_{0}+\sum_{i=1}^{n} c_{i} P_{i}+\sum_{i=1}^{n} \sum_{j=i}^{n} c_{i j} P_{i} P_{j}
$$

The location of the sampling points was defined referring to Box-Behnken sampling matrix technique; subsequently the estimation of the coefficients $\left(c_{i}\right)$ was carried out through the least squares method.

Box-Behnken design was introduced in order to limit the sample size as the number of parameters grows. The sample size is kept to a value which is 
sufficient for the estimation of the coefficients in a second degree least squares approximating polynomial [26].

The sensitivity analysis was performed by using the probabilistic tool of ANSYS software, which automatically defines the range of variation for the input variables (Table 8) in terms of mean value and standard deviation (Gaussian distribution).

Results of RSM are recapped in Table 9.

Table 8 .

RSM: Input variable functions

\begin{tabular}{|c|c|c|c|}
\hline Parameter & Distribution & $\begin{array}{c}\text { Mean } \\
\text { value }\end{array}$ & $\begin{array}{c}\text { Standard deviation } \\
\text { deviation }\end{array}$ \\
\hline P1 & Gaussian & 3.0 & 0.5 \\
\hline P2 & Gaussian & 4.0 & 0.5 \\
\hline P3 & Gaussian & 2.5 & 0.5 \\
\hline P4 & Gaussian & 3.0 & 0.5 \\
\hline P5 & Gaussian & 3.0 & 0.5 \\
\hline P6 & Gaussian & 3.0 & 0.5 \\
\hline
\end{tabular}

Response Surface Method results

\begin{tabular}{|c|c|c|c|c|}
\hline Parameter & $\begin{array}{c}\text { Mean value } \\
{[\mathbf{H z}]}\end{array}$ & $\begin{array}{c}\text { Standard } \\
\text { deviation }\end{array}$ & $\begin{array}{c}\text { Min } \\
{[\mathrm{Hz}]}\end{array}$ & $\begin{array}{c}\text { Max } \\
{[\mathrm{Hz}]}\end{array}$ \\
\hline FREQ 2 & 380.8 & 31.28 & 193.8 & 438.6 \\
\hline FREQ 4 & 584.9 & 13.50 & 480.8 & 599.7 \\
\hline FREQ 6 & 600.9 & 35.28 & 416.6 & 764.5 \\
\hline
\end{tabular}

The Response Surface diagrams, reported in Figs. 10-11, confirms, coherently to MCS results, that for $\mathrm{P} 3$ equal to 2.5 the difference between numerical and experimental frequencies is minimized. In order to increase the value of FREQ6, P6 should range between 2.6 and 3.6; at the same time, an increase of FREQ2 may be reached if P6 is lower than 3. By taking into account such trends, a compromise value of 2.8 was chosen for P6. The values of the other input parameters were not significant and were imposed equal to 4 (Table 10).

Once the values of the input parameters were found (Table 10), a new evaluation of modal parameters was performed and the obtained results showed a satisfactory improvement of correlation levels between numerical and experimental natural frequencies and modes' shapes (Table 11).

Response Surface Method optimal solution

\begin{tabular}{|l|l|l|l|l|l|}
\hline P1 & P2 & P3 & P4 & P5 & P6 \\
\hline 4.0 & 4.0 & 2.5 & 4.0 & 4.0 & 2.8 \\
\hline
\end{tabular}




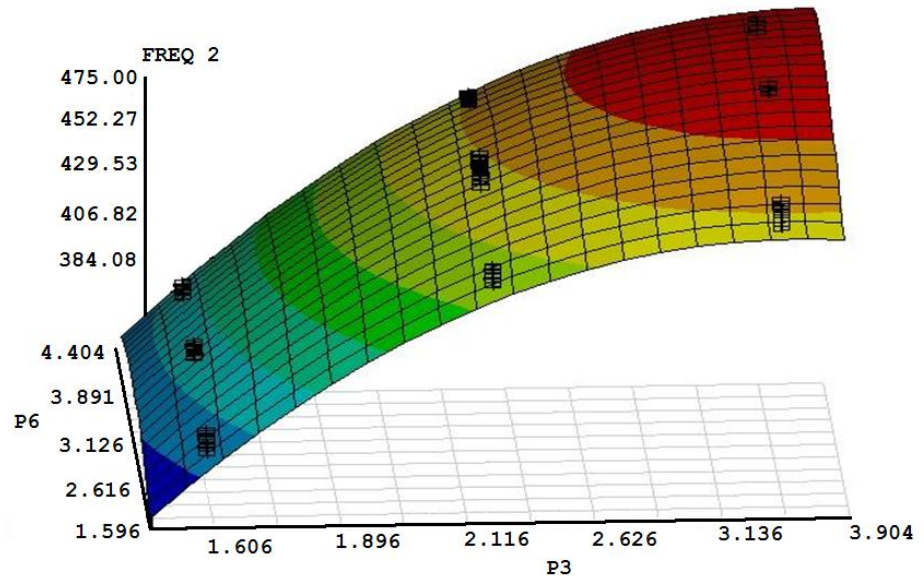

Fig. 10. Response surface: FREQ 2 vs. P3 and P6

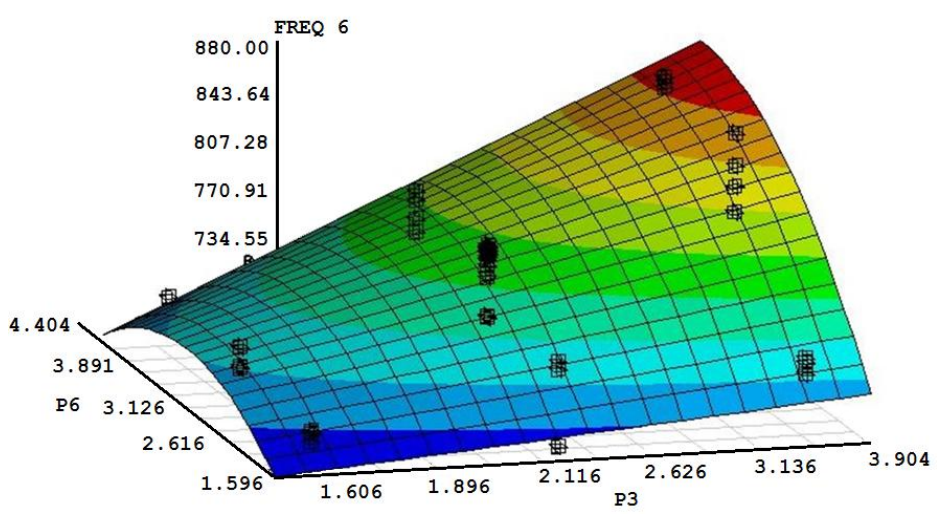

Fig. 11. Response surface: FREQ 6 vs. P3 and P6

\section{Conclusions}

The results obtained from an experimental modal analysis campaign performed on an aircraft combustor-rig were used to validate and optimize a finite element model of the structure. Both free and clamped boundary conditions were investigated. A very good correlation between the experimental and numerical modes was obtained, for the free-free boundary condition, up to $800 \mathrm{~Hz}$. On the contrary, in the case of the clamped boundary condition, the finite element model proved to be adequate for reproducing the mode shapes of the investigated structure, while the natural frequencies were systematically overestimated. Since this is reasonably due to the combustor structure constraints which are not infinitely rigid, as assumed in the model, a sensi- 
New correlation results

\begin{tabular}{|c|c|c|c|c|}
\hline \multicolumn{2}{|c|}{$\begin{array}{c}\text { Numerical results } \\
\text { (FEA) }\end{array}$} & $\begin{array}{c}\text { Experimental results } \\
\text { (EMA) }\end{array}$ & Difference & MAC \\
\hline $\begin{array}{c}\text { Mode shapes } \\
\#\end{array}$ & $\begin{array}{c}\text { Frequency } \\
{[\mathrm{Hz}]}\end{array}$ & $\begin{array}{c}\text { Frequency } \\
{[\mathrm{Hz}]}\end{array}$ & {$[\%]$} & {$[\%]$} \\
\hline 1 & 394.47 & 347.24 & 11.97 & 21.7 \\
\hline 2 & 418.77 & 360.50 & 13.91 & 31.0 \\
\hline 3 & 441.60 & 423.83 & 4.02 & 10.0 \\
\hline 4 & 568.55 & 469.13 & 17.49 & 53.7 \\
\hline 5 & 592.84 & 575.51 & 2.92 & 78.5 \\
\hline 6 & 674.16 & 690.94 & -2.49 & 47.7 \\
\hline 7 & 801.51 & 782.90 & 2.32 & 6.4 \\
\hline
\end{tabular}

tivity analysis, implementing Monte-Carlo simulation and Response Surface method, was performed on few - reasonably selected - natural frequencies providing an improvement on the percentage difference value and MAC index.

\section{Acknowledgements}

The authors wish to acknowledge AVIO Aerospace Propulsion S.p.A. for having supported all research activities which made possible the publication of this paper.

Manuscript received by Editorial Board, January 14, 2016; final version, July 06, 2016.

\section{References}

[1] G.J.J. Ruijgrok and D.M. van Paassen. Elements of Aircraft Pollution. Delft University Press, 2005.

[2] Rolls Royce. The Jet Engine, The Technical Publications Department Rolls-Royce plc, Derby England, 1996.

[3] B.H. Jennings and W.L. Rogers. Gas Turbine Analysis and Practice. Dover Publications, New York, 1969.

[4] M.P. Boyce. Gas Turbine Engineering Handbook, Gulf Publishing, Oxford, 2006.

[5] www.cleansky.eu (Clean Sky official website).

[6] T.C. Lieuwen. Static and dynamic combustion stability, chapter 3.1.1. The Gas Turbine Handbook. National Energy Technology Laboratory, pages 197-203, 2006.

[7] F. Amoroso, A. De Fenza, R. Pecora, V. Cirillo and L. Lecce. Dynamic and acoustic analysis for a low NOx emissions combustor. 20th AIDAA Conference, Milan, Italy, 2009.

[8] M. Cesare, R. Sues, and Y-T. (Justin) Wu. Probabilistic high cycle fatigue (HCF) of jet engine blades. 19th AIAA Applied Aerodynamics Conference, Paper 81-1259, Anaheim, CA, 2001.

[9] R.A. Huls. Acusto-elastic interaction in combustion chambers. $\mathrm{PhD}$ thesis. University of Twente, Enschede, The Netherlands, May 2006. 
[10] L.L. Beranek. Noise and Vibration Control Engineering. John Wiley \& Sons, 2006.

[11] R.A. Huls, J.F. van Kampen, P.J van der Hoogt, J.B. Kok and A. de Boer. Acoustoelastic interaction in combustion chambers: modeling and experiments, Journal of Engineering for Gas Turbines and Power, 130(5):051505, 2008, doi:10.1115/1.2938391.

[12] Y. Xiong, M. Dede and M. Moscinski. Combustor modeling and design with uncertainties, 48th AIAA/ASME/ASCE/AHS/ASC Structures, Structural Dynamics, and Materials Conference, AIAA Paper 2007-1871, Honolulu, 2007.

[13] J.P. Den Hartog. Mechanical Vibrations. Dover Publications, 1985.

[14] W. Weaver Jr., S.P. Timoshenko and D.H. Young. Vibration Problems in Engineering. WileyInterscience, 1990.

[15] ANSYS - Advanced analysis techniques guide.

[16] R.M. Lin and D.J. Ewins. Model updating using FRF data. In Proceedings of the 15th International Seminar on Modal Analysis, pages 141-162, Leuven, Belgium, 1990.

[17] W. D'Ambrogio, A. Fregolent and P. Salvini. Updatability conditions of non-conservative FE models with noise on incomplete input-output data. In Proceedings of structural dynamics modelling test, analysis and correlation, pages 29-38, 1993.

[18] S. Lammens, W. Heylen and P. Sas. Model updating using experimental frequency response functions: case studies. In Proceedings of structural dynamics modelling test, analysis and correlation, pages 195-204, 1993.

[19] R. Pascual, J.C. Golinval and M. Razeto. Model updating using operating deflection shaps. In Proceedings of XVI international modal analysis conference, pages 12-18, Santa Barbara, CA, 1998.

[20] C.J. Everett and E.D. Cashwell. A Monte Carlo Sampler. LA-5061-MS Informal Report, Los Alamos Scientific Laboratory of the University of California, 1972.

[21] E.P.G. Box and N.R. Draper. Response Surfaces, Mixtures and Ridge Analyses. Wiley, 1987.

[22] P. Erto. Probabilità e Statistica per le Scienze e L'ingegneria (Probability and Statistics in Science and Engineering). 3 edition, McGraw-Hill, 2009 (in Italian).

[23] G. Petrone, V. D’Alessandro, F. Franco, B. Mace and S. De Rosa. Modal characterisation of recyclable foam sandwich panels. Composite Structures, 113(1):362-368, 2014.

[24] J.K. Lee and Y.S. Park. Modal parameter estimation in structural system using complex envelope signal. In Proceedings of the 10th IMAC, pages 167-172, San Diego, CA, 1992.

[25] A. De Fenza, E. Monaco, F. Amoroso and L. Lecce. Experimental approach in studying temperature effects on composite material structures realized with viscoelastic damping treatments. Journal of Vibration and Control, 22(2):358-370, 2016.

[26] M. Cavazzuti. Optimization methods. From theory to Design Scientific and Technology Aspects in Mechanics. Springer, 2013.

\section{Analiza wpływu więzów zewnętrznych na właściwości dynamiczne zespołu samolotowej komory spalania o niskiej emisji zanieczyszczeń}

Streszczen ie

Potrzeba redukcji zanieczyszczeń stawia wobec inżynierów wymaganie projektowania samolotowych komór spalania, które charakteryzują się ubogim spalaniem przy relatywnie niskich temperaturach. $\mathrm{W}$ tych warunkach mogą łatwo powstawać zjawiska niestabilności płomienia i wynikające stąd pulsacje ciśnienia, które mogą poważnie uszkodzić strukturę komory spalania lub/i zmniejszyć jej trwałość zmęczeniową.

Wynika stąd potrzeba studiów nad dynamiką strukturalną komory spalania i interakcjami między zjawiskami termicznymi i akustycznymi. Metoda elementów skończonych jest narzędziem dość niezawodnym i powszechnie stosownym, odpowiednim do takich studiów. Z drugiej strony, proces 
idealizacji może prowadzić do wyników, które są bardzo odległe od rzeczywistości, jeżeli w założeniach przyjęto nadmierne uproszczenia.

Modelowanie więzów jest sprawą kluczową dla wszystkich analiz dynamicznych metodą elementów skończonych. Błędna symulacja więzów może istotnie zagrozić całej analizie, nawet gdy korzysta się w niej z bardzo dokładnych modeli strukturalnych o udoskonalonej siatce.

W artykule zaprezentowano podejście probabilistyczne by scharakteryzować wpływ więzów zewnętrznych na właściwości modalne zespołu samolotowej komory spalania. Najpierw przeprowadzono walidację modelu elementów skończonych drogą porównania wyników doświadczalnych i obliczeniowych w warunkach swobodnych (bez więzów). Gdy potwierdzono prawidłowość modelu, zbadano wpływ sprężystości więzów na częstotliwości drgań własnych stosując metodę probabilistycznego projektowania symulacji (PDS). Korzystając ze specjalnego narzędzia opracowanego w oprogramowaniu ANSYS, wykonano wstępną analizę statystyczną metodą symulacji Monte Carlo (MCS). Jej wyniki skorelowano następnie z wynikami doświadczalnymi stosując metodę powierzchni odpowiedzi (RSM). 